\section{National Socialism and 'Non-Aryans' in Germany}

IT may be impossible, as has been maintained on occasion, to indict a nation; but the lettor in which Mr. James G. McDonald resigns office under the League of Nations as High Commissioner for Refugees from Germany does more. By the terms of that letter, which cannot be questioned seriously, Germany stands condemned as guilty of a persecution no less barbarous and an intolerance as rigid and as crass as any that figure in the annals of the Middle Ages. Though economic forces have taken the place of open massacre, the end in due time will be no less certain. For even half a million Jews, and with them the 'non-Aryans' who are to share their fate, cannot in modern conditions so organise themselves as to avoid being ground to extinction between the alternatives of destitution and an exile which leaves them practically penniless. As Mr. McDonald points out, the conditions created by the Nuremberg legislation of September last have destroyed the utility of the office he now lays down, and have passed beyond the capacity of the activities of philanthropic and other bodies by whom provision has been made for all but some seventeen thousand of the eighty thousand refugees who have left Germany in the last three years. This legislation, by confining Reich citizenship to 'Aryans' and those who accept the National Socialist conception of the State, has deprived Jews and 'non-Aryans' of all rights as citizens-not only of the right to hold office, but also of the right to make a living by the exercise of profession, trade or business as between 'Aryan' and 'non-Aryan' and, debarring them from all social relationship except inter se, has sought to create a social and intellectual ghetto, in which it will become increasingly difficult for them to survive.

The changed conditions, Mr. McDonald holds, justify collective action on the part of the League of Nations. Half a million people are being crushed for their inability to comply with a condition beyond their control, namely, an Aryan racial origin, and with them are penalised all who are unable to accept the Nazi doctrine of complete subordination of the individual to the State, but still cling to the ideal of freedom of thought and individual liberty, which was until recently, in theory at least, a fundamental doctrine of citizenship. Hence Germany, by creating a situation for which the obvious relief is expatriation on an extended scale, endangers the economic stability of her neighbours and the peace of Europe. Further, she has laid herself open to the charge of differential treatment of a minority, which she herself recognises implicitly as such, thus violating a principle of the public law of Europe, which has been accepted as a safeguard of minorities for the past hundred years. It is scarcely necessary to point out once more the vital interest to science of this strugglo for freedom of the individual, irrespective of race, creed or conviction. Not only would the work of many men of science, not a few indeed of international eminence, have been lost to the world, had it not been for the assistance afforded by other countries, but it may also be taken as axiomatic that a political faction which seeks to control and mould the roligious belief of its countrymon to support its own political views, will not lightly allow scientific research and the advancement of knowledge to proceod in search of truth without regard to extraneous circumstance.

\section{Retirement of Sir Robert Robertson, K.B.E., F.R.S.}

DURING the fifteen years that Sir Robert Robertson has filled the post of Government Chemist, the work of the Government Laboratory in Clement's Inn Passage has increased very greatly, both in amount and complexity. The number of samples dealt with has grown in the proportion of $5: 3$ and now amounts to more than half a million a year. Much of the increase is due to the additional import duties that have been introduced, but a considerable proportion of it is caused by the constant call for more governmental control in various directions. The Government, Chemist is a member of a number of committees appointed by Crown departments, and on many others he is represented by members of his staff; partly for this reason, the personnel of qualified chemists has had to be raised gradually from thirtyeight to seventy. In spite of all these official activities, Sir Robert has found time to advance the cause of science in other ways. He has carried out important researches on the infra-red spectra of ammonia, phosphine and arsine, and his investigations of diamonds led to the discovery that there are two varieties of this precious stone with distinctive atomic structures. In 1926-29 he was socretary of the Royal Institution, and since then as treasurer ho has been responsiblo for raising large sums of money for rebuilding and for the endowment of research.

Practically the whole of Sir Robert's eareer has been in Government service: for some fifteen years he was a chemist at the Royal Gunpowder Factory, Waltham Abbey. When he first went there, the manufacture of cordite was quite a new thing, but before he left he had carried out important investigations on its stability. From there he went to Woolwich as Director of Explosives Research in 1907, so that when the Great War broke out he was in a position to do much to assist the enormous developments in the manufacture and control of explosives. For this he was made K.B.E., and he was also elected to the Royal Society. When Sir Robert retires on April 17, he will be succeoded by his deputy, Dr. J. J. Fox, who has served in the Government Laboratory for some thirty-six years, during which time he has also worked under Sir T. E. Thorpe and Sir J. J. Dobbie. Dr. Fox studied physies and chemistry at the East London Technical Schools, and afterwards continued his chemical studies at the Royal College of Scionce. $\mathrm{He}$ has always been specially interested in physics and the application of physical methods to chemical analysis, upon which he has published much work. He collaborated with Sir Robert Robertson in the rosearches already mentioned on infra-red spectra and the diamond.

(Continued on p. 25.) 